Campbell University School of Law

Scholarly Repository @ Campbell University School of Law

1983

\title{
The Evangelical Rediscovery of Law and Politics
}

Lynn Buzzard

Campbell University School of Law, buzzardl@campbell.edu

Follow this and additional works at: https://scholarship.law.campbell.edu/fac_sw

\section{Recommended Citation}

Lynn Buzzard, The Evangelical Rediscovery of Law and Politics, 1 J. L. \& Religion 187 (1983).

Available at: https://scholarship.law.campbell.edu/fac_sw/61

This Article is brought to you for free and open access by the Faculty Scholarship at Scholarly Repository @ Campbell University School of Law. It has been accepted for inclusion in Scholarly Works by an authorized administrator of Scholarly Repository @ Campbell University School of Law. 


\title{
THE EVANGELICAL REDISCOVERY OF LAW AND POLITICS
}

\author{
by Lynn Buzzard*
}

John C. Pollack, summarizing a study conducted by the Connecticut Mutual Life Insurance Company, declared that "moral issues through religion have vaulted to the forefront of political dialogue." And he concluded, "Something unusual is happening."

Indeed, Pollack seems right that "Something unusual is happening." The sharpness with which moral issues have entered into political dialogue is perhaps unprecedented since the slavery issue. Not an insignificant amount of the dialogue and surely an aspect of its unusualness is the entrance of evangelicals into the political arena-a presence again that looks for precedents as far back as the anti-slavery crusades.

The foray into politics of religious conservatives committed to personal conversion, biblical authority and the Lordship of Jesus Christ is all the more striking because these evangelicals were, after all, the ones who a decade ago were criticised for their steeple religion, their edifice complex, the comfortable pews and their avoidance of this world in favor of other wordly and privatistic religion. Both socially concerned "liberal" Christians and the nonreligious community soundly criticized these "escapist" religionists with the pietistic songs and emotional revivals. Now that these same persons have become active, left the pews for the streets and the ballot boxes, they are, alas, still unloved. They are criticised for mixing church and state, for seeking to enforce their private morality and for not sticking to religion.

The emergence of politically conservative evangelicals in the raw world of politics has received broad attention. Of course, much of the attention has been negative. Cartoonists have taken delight, essayists plundered, and even Barry Goldwater had a suggestion for straightening out some of the activities of the most notably active conservative minister. And of course, world events in Iran and Ireland, not to mention Jonestown, give much illustrative content to criticisms about religious involvement in public.life.

It is with much hesitancy that I address the issue of the mean-

- Lynn Buzzard, a Methodist pastor and a lawyer, is Executive Director of the Christian Legal Society. 
ing of the evangelical political agenda. The issue is too complex for instant analysis, it is too early in the process for historical analysis. Besides the categories are so elusive. The word "evangelical" itself is slippery, for it means radically different things in divergent American religious communities. I suspect that when the populist uses the word it includes a spectrum from fundamentalists on the right to the Sojourners, Hatfield to Helms, Ron Sider to Rousas Rushdoony - persons all familiar in evangelical circles, but all so different. When a Wheaton College professor uses the word he may be seeking to distinguish himself from "fundamentalists" whose doctrines he may in general accept but whose style and whose easy acceptance of cultural and regional accretions to the Gospel he may reject. I suspect that the reader of this paper has in mind primarily those elements of the political right in evangelicalism who have been symbolized, if not summarized, by Moral Majority and Rev. Jerry Falwell.

The evangelical movement is, however, much more diverse than often thought. I recall a speaker a few years ago who suggested there were three great issues on which all Christian lawyers could agree. We waited eagerly to hear them. He announced they were: capital punishment, abortion and public aid to private education. Whereupon a listener raised his hand to inquire, "On which side are we?" Indeed evangelicals are not necessarily of one mind on all issues. They encompass those like the Sojourners who are deeply concerned with issues of international justice, human rights, the poor and oppressed, justice, the cities, disarmament, and economic justice. They emphasize biblical demands for justice and peace, and the model and command of Jesus Christ to stand over against this culture. They criticise their conservative brethren for uncritical Americanism. The Hatfields, Colsons, and countless others share many of these concerns though perhaps with a less strident voice. The evangelicals also encompass broad aspects of the charismatic movement, many Baptist groups, and at least in some ways the Anabaptist traditions. All of these offer sharp contrasts with the political agendas of the more vocal and politically conservative evangelicals. But as much as the Sojourners and Moral Majority may disagree, they have not only their spiritual and biblical commitments in common, but share a relatively recent commitment to public affairs and cultural responsibility. Whether socially conservative or liberal, whether focusing on international human rights, or criticizing gay rights ordinances, they share a new concern for society, for the state, 
for Christian involvement in shaping society. They share a discovery of law and politics.

A question which this new interest among evangelicals inevitably raises is why NOW-why at this particular juncture have evangelicals of both left and right assumed an interest, and a fairly urgent one, in law, justice, and the social order?

It is beyond this paper to detail all the elements, but surely part of it is a maturing of evangelicalism itself, its movement into respectability, and the influence of increased theological education among its clergy. One also might point to the much broader "coming out" of evangelicals. The Jesus people, the youth revivals of the 60 's, the religious components, though by no means dominated by evangelicals, or the Vietnam protests, all have given religion a new aggressiveness. "Born-again" became a household word, a President declared he was born-again, TV programs carried the message to millions. This aggressive new religion, of course, is seen not only among evangelicals but among many religious groups, most notable, perhaps, the "cults." The very publicness of Christian faith has helped create an identity, and with an identity a sense of capacity and strength.

But while these internal sociological factors play a role, they do not fully explain the emergence of evangelicals into politics, on either the right or left. More was surely necessary to drive the good reverends from their accustomed haunts to the halls of Congress and the homes of America with their business reply envelopes. What factors in contemporary society have created pressures significant to overcome the inertia of pietism and privatism.

Two elements seem important in this process - the first, environmental, namely a perception of a moral crisis in society and government that threatens the fabric of our life. And secondly, a more principled element, the development of a theology which requires cultural engagement. This latter element is probably less significant in the short run but more revolutionary in the long run.

\section{A CRISIS}

The environmental factor which drives many evangelicals into the public arena is a deep and compelling sense of crisis. Indeed it is felt by others, felt by society's poets, artists and philosophers. It is the feeling which creates "One Flew Over the Cuckoo's Nest," the novels of Graham Greene and George Orwell, and leads to the exis- 
tentialist's ultimate choice of suicide. It is that sense of crisis which Yale President A. Bartlett Giametti described as the "accent of the Apocalypse." Giametti, naturally, what else could an educator do, warned the incoming class of 1984 not to be persuaded by this end of the millenium rhetoric, this "fatigue masquerading as a philosophy." But the "accent" Giametti observed is indeed strong and to many, compelling. It can hardly be dismissed by an appeal to fatigue.

It is precisely this sense of crisis in our society, a radical shift in culture which is caught up in a different idiom in a recent volume by Daniel Yankelovich. Yankelovich, commenting on the changes taking place in contemporary American culture, writes of the character of the tensions in our culture. "A recurring image comes to mind," he writes, "the image of the earth, moving deep beneath the surface and so transforming the landscape that it loses its comfortable familiarity. .. [the] giant plates of American culture are shifting relentlessly beneath us." Yankelovich's vision of a cultural upheaval sending tremors throughout our sociological and psychological body is reinforced by the title of his article in Psychology Today, "A World Turned Upside Down." He concludes, "we are not going back to the old values," but rather in the midst of an irresistible cultural revolution which constitutes a "decisive break" with the past. It is, he insists drawing on an image of Hannah Arendt, the creation of a "new story." The author's image is powerful and catches up the scope of the changes in contemporary society. There does indeed seem to be a straining of the plates, a shaking of the foundations. Is this merely a product of fatigue? There is the disturbing objectivity of the nuclear arms race, world starvation, the depletion of vital world resources, the growth of totalitarianism, the complex issues created by technological advances in bioethics. Or one can name with nouns the "accent of the apocalypse"-Cambodia, Vietnam, Ireland, Afghanistan, Southern Africa, El Salvador. The coalescing of economic uncertainty, the emergence of pluralistic and competing values, the rejection of many old traditions and structures, the ecological plight of planet earth, the conciousness through instant communications of the tragedies of the world, have created enormous pressures. The failure of the hopes and little gods of both western and eastern culture, the impotence of flower children and social reformers-all are but a few of the factors that cause us to feel that the grounds upon which we have built our ethos are shifting and shaking. Nor has the retreat from the world into self- 
fulfillment, self empowerment and narcissistic searches for identity brought relief.

Now if Arendt's image adopted by Yankelovich of the emergence of a "new story" about ourselves, about American is accurate, then it is not at all surprising that evangelicals, with an investment in the old story are nervous, disturbed, confused and sometimes angry-both at the content of the new story and the authors who are writing it.

Evangelicals are, however, badly split on what parts of the new story are most disturbing. For the evangelicals on the left, it is the plots of military escalation, the growing economic injustice. For the evangelical on the right, the most disturbing aspects have been in the personal moral arena and the felt erosion of the religious-moral fabric which informed the American vision. Perhaps their moral vision has been too narrow, but can anyone seriously challenge the conviction of these evangelicals that the moral character of American society is being substantially transformed. These evangelicals note with alarm the rapidly growing divorce rate, alcoholism, drug addiction, teenage suicides, organized crime, white collar advocacy of life styles offensive to traditional Christian morality, an explosion or pornography and obscenity, the exploitation and dehumanization of sexuality-is it any wonder the evangelical feels the ground shaking, senses the accent of the apocalypse.

However simplistic at times the interpretation of the causes of these shifts may be, the evangelical seems right in perceiving a radical new story being written. He senses a crisis in western society so profound that nothing short of a reawakening of moral commitments and prophetic religion including the arousal of the church may save the character of our society.

\section{A CONSPIRACY}

There is more to the evangelical frustration however than merely a struggle with personal sin. Were it merely a matter of private evil, the evangelical would not likely be taking his crusade into courts and electoral districts. What heightens the evangelical's frustration and drives him to the polls is the perception that major social and political forces are willing co-conspirators in the assault on fundamental morality. The educational bureaucrats, the media moguls and the government in its courts and regulatory bureacracies are seen as contributors to the moral crisis-a contribution by both 
omission and commission. Government has ceased to restrain evil, ceased to call its citizens to moral conduct. The media fosters violence, exhalts immorality. Schools are undisciplined, valueless at best, shaped by relativism.

While the conservative may be viewing only a partial truth, there is substantial evidence to support his perception that public institutions have succumbed to laissez faire morality. Probably in the memory of the youngest person here was a time when the laws of almost every state provided criminal penalties for homosexual conduct, regulated pornography, outlawed most abortions, made divorce difficult. Now the law has radically shifted its role. No longer a preserver of values of the past, it has decriminalized, then given legal status, and finally protected conduct formerly prohibited.

These persons note with alarm decisions such as that of the Massachusetts high courts striking down attempts to prohibit the use of children in pornography. They object to sex education programs which call for exploring a variety of left styles including homosexuality and group marriage, and curricula that suggest public school students discuss whether they are satisfied with the size of their sex organs.

Don't blame the evangelical for feeling that things are not well in River City. Is this radical change because we now have gained great new moral insight? Has a new jurisprudence been affirmed by the body politic? Where are the institutions which support a moral fabric? These are the troubling questions to the evangelical. He is not at all impressed with the simplistic answers that often are given: "times have changed," "you can't legislate morality," "this is a free country." Such answers are either patently false, or beg the question.

\section{An Assault on Religious Liberty}

But again, at least for the fundamentalist wing and not a few more mainline evangelicals, this is still not the whole story. For in addition to the perception that government and other national leadership promote policies that undermine public and private morality, there is a further sense that there is an assault as well on the church and religious conscience-an attack on religious liberty. Not only will the state not endorse your religious views, it will limit your right to exercise them. Thus some evangelicals are not only righteously indignant, they believe they are in a fight for freedom and survival. 
Now to those who do not follow issues of religious liberty this may appear to be inconceivable. Certainly if one looks merely at the scope of religious TV, the vigorous activity of religious individuals in airports, and the fact that all three of our last election's presidential candidates described themselves as "born-again" Christians, one might believe religious liberty was the least threatened of our freedoms. Yet serious issues of religious freedom are now confronting the courts and legislatures. The very scope of cases now working their way through the courts is testimony that the state and religion are on different courses, a fact acknowledged in U.S. News and World Report in the final issue of 1980 when it declared, "the stage is set for a climactic confrontation over disputes of faith and statecraft."

A good deal of the clash between church and state derives from the expansion of each sphere. There is a seemingly inexorable tendency of government, like perhaps any human institution, to seek control and power, to expand the zone of its dominance and the sphere of its authority. Government and law invade our lives, control our businesses, shape our schools. They assess, demand, codify, regulate, certify and license. They tax, aid and insure. This expansiveness, combined with an often audacious claim to "right" and authority is offensive to many with strong individualist traditions. An expansive government tends to consume the sphere between the individual and the state, areas traditionally dominated by associational life-those structures essential for communities, for identity and the dispersion o responsibility. They are the mediating structures in society. But an expansionist government tends to monopolize these zones by regulation, at least.

Expanding government has clashed directly with religious institutions such as schools, nursing homes, day care programs, hospitals. Religion is also expanding as organized religion has become more involved in public institutions and ministries. Its involvement in broadcasting, education and relief efforts are enormous. Such expansion into arenas of government involvement, as well, has led to inevitable clashes with the promise of supporting a number of law firms for years to come.

Besides these jurisdictional struggles, however, there have been more substantive changes in the relationship between church and state and a significant shift in the character of cases now before the courts. No longer are the cases primarily about Establishment Clause prohibitions and rooting out religion from a dominant place 
in public life, but about government regulatory powers over religion, individual rights of conscience, religiously based exemptions, and concerns related more to free exercise, equal protection and free speech than to establishment issues. Evangelicals are disturbed with decisions by U.S. district courts in Missouri and Washington upholding university policies prohibiting religious student groups from meeting at the universities though those universities otherwise encourage student groups to meet. Why in an age that prides itself on civil rights and free speech, and when student rights are loudly defended, is the one group denied those rights those students whose purposes are religious? A Christian student group was even refused permission to use the Free Speech Platform at one university.

Dean Kelly in a recent address listed seventeen areas of growing concern over government activities threatening religious liberty and free exercise. Included were: government regulation of financial solicitations, lobbying disclosure requirements, grand jury interrogations of church workers, and subpoenas of church records.

The effort by the State of California to apply the charitable trust theory to the assets of the World Wide Church of God has caused alarm in the evangelical community. The community sees danger in a notion that the state may decide what constitutes an appropriate use of church monies. This posture of the state was described by Tony Jackson, an attorney representing the Church, as "socialized religion."

Or there is the effort in over ten states to adopt "conservatorship" statutes aimed at "cults" which would allow parents to obtain temporary custody of their adult children when those children exhibit one or more of a number of characteristics. In New York those characteristics included sudden changes in basic values, lack of appropriate emotional response, weight loss, changes in friendships and rejection of former lifestyles. They seem little else than anticonversion statutes.

Or the attempt by the IRS to revoke the exemption of Bob Jones University because its internal policies of prohibiting interracial marriage on religious grounds do not comport with public policy. Without condoning at all the University's racial views, the notion that there is an "approved" religion which merits the state's favors is abhorrent.

Or the efforts in many states to apply sweeping state standards to private Christian schools-standards including requirements as 
to teacher certification, curriculum guidelines, student testing, and textbooks. So exhaustive have been these regulations, and subject to such extensive discretion by state education authorities, that court action has in some states struck down all but the health and safety rules.

Or what of the order of a government agency that a realtor who had displayed a Christian symbol on the business stationery, but without any evidence or claims that there had been any discrimination, must remove all such religious symbols and language, and engage in an affirmative action program including advertising in newspapers predominantly read by Jewish persons with specification of names of papers, percentage of advertising in certain media, and other detailed prescriptions.

Or the statement of a federal court that allowing high school students to assemble before school and pray was "too dangerous to permit" and the declaration of a district court that "religious speech is not entitled to the same protection as political speech."

Or the position originally taken by the Los Angeles County Attorney's office and that of several other cities that regular home Bible studies may not meet without a permit for a zoning variance.

Cases such as these multipled across the country give content to the growing sense that religious liberties are not the favored child of the First Amendment, but are in fact being swallowed up in a sea of compelling state interests and an overemphasis on the Establishment Clause to the exclusion of the Free Exercise Clause. The religion clauses, once arguably giving very special status to religious liberty, now seems an impediment. Evangelicals join some justices of the Supreme Court in suggesting that what we have is not neutrality, but functional hostility to religion-a growing commitment to exercise from public life, and confine to the chapel and home, the religious life of our people.

To be sure there is great deference to religion in the context of its worshipping functions. But when it seeks to fulfill its larger cultural mandate in education or in social services, when it moves into the public arena, there inevitably appears the government regulator, tax official, labor department official, zoning officer and health official, with standards, policies, prohibitions, forms - all insisting that the state has a public duty, a compelling state interest, and thus the rules-rules so sweeping as to denude the institution of its religious character-destroying the very inspiration and mission that had led 
to its creation. The pressure of present policy according to William Ball is to seek to "compress religion into the space beneath the steeple."

These perceptions, that the structures of society are hostile to the values of traditional religion and that they are attempting to squeeze religion into narrower confines, combine in a conviction that a new religion now dominates the philosophic landscapenamely the religion of secular humanism, a religion which denies theistic presuppositions, rejects moral absolutes, makes man and science the measure of all things and sees religion as archaic, disruptive of community, damaging to psychological health-something at best to be tolerated, but certainly ultimately to be removed by enlightened persons. And certainly nothing that has any right to participate in the public arena. Martin Marty, University of Chicago Theology Professor, in a syndicated column carried in the Chicago Tribune rightly criticised the religious right for an exaggerated perception of the power of secular humanism, and for the tendency of the right to blame humanism for every evil in our society-a sort of scapegoat. On the other hand surely the conservative has not introduced some novel notion in the suggestion that there are operative and shaping philosophies in a culture. Nor is it strange to suggest that those philosophies may rise to the level of a religion-at least in the sense that they demand obesiance, are founded on "faith," and are the basis for inclusion and exclusion from the realm of the enlightened. In fact liberal Christianity has long pointed to the power of systems and structures. The liberal has often complained that conservatives with their individualism have failed to recognize the importance of structural evil and philosophic principles. One may point today to South Africas' apartheid or earlier Nazi Germany, or endemic racism in American culture, or our materialism as examples of presuppositional biases. To be sure secular humanism has no thrones or rituals, but that hardly makes it less of a compelling philosophy.

Marty also suggested that the attack on secular humanism was a poorly disguised assault on pluralism. While opponents of secular humanism may evidence such a rejection of a broader liberty, that is not necessarily the case. We must in fact carefully distinguish a secularist governing philosophy from genuine pluralism. Pluralism may indeed be threatening to many religious persons, but if we are to take seriously freedom and human rights, then Christians must not only grudgingly accept, but affirm pluralism. In fact there are 
many positive elements of pluralism from a religious perspective. It is, after all, the essential context for evangelism; it invites the religious community to take its apologetic task seriously. It forces basic decision-making about life's values and one's personal commitments. Christians, it seems, did quite well in the first century without government aid or prayer breakfasts. But while affirming pluralism, there is a version of pluralism which is unacceptable namely, a pluralism which exludes, often on questionable constitutional grounds, religion from the public life, while inviting every other form of ideal and value to be freely expressed. It is the sort of pluralism which encourages in public education any ideas which come from contemporary philosophy, psychology and politics, no matter how bizarre and passing, but rises up to strike down any suggestion that in the mix of ideal one might include notions that come from great religious traditions. An appeal to Marx, to Marcuse, to Sartre, to McLuhan is fine, but an appeal to Jesus is not. That, to evangelicals, does not seem to be pluralism, that does not seem to be the marketplace of ideas. That is a constricted, secularized pluralism. One is reminded of the suggestion of the English historian E.R. Norman that pluralism is a word a society employs to describe itself during its transition from one orthodoxy to another.

\section{A Theology Demanding Public Involvement}

The perception of a crisis is, however, only part of the picture of the factors which have driven clergy and the pious from their churches and cloister. Far more significant for the long run is the theological posture which is developing not only on the "right" in evangelicalism, but even among many who are quite uncomfortable with the agenda of the right. It is a theological posture with strong roots in Scripture and in evangelical history. It is a theology which rejects pietism as an adequate response to discipleship, rejects an exclusively eschatological orientation, and suggests that the arena of discipleship and ministry includes the present order. It demands cultural responsibility. While not holding the optimism of the classic social gospel movement, it does declare that the gospel is profoundly social.

There has been, again as the noted evangelical theologian, Carl Henry, indicates, a "long smouldering uneasy conscience over sociopolitical detachment" among evangelicals. That attachment is being radically altered today on many fronts. Evangelicals are taking ac- 
tive roles in concerns for justice, peace, human services, urban problems - to be sure, a mere beginning, but still an awakening of public ministry and responsibility.

Behind this is a commitment to a prophetic vision of salvation, of the kingdom of God and of servant-discipleship that is pressing the evangelical into the world he once shunned. Its roots are Old Testament prophets and concepts of covenants. It is a rejection of the counsel of John Locke that "the only business of the church is the salvation of souls, and it no way concerns the commonwealth."

Central to this prophetic perspective is the conviction that God is a God of history. He is perceived precisely through the stuff of history-a salvation history made up of kings, wars, slave rights and turf. There is no escape to "religion" in this commitment. It is out of the raw history of Abraham, Isaac and Jacob and places like Bethel and Bethlehem that the faith is born and nurtured. In this sense Christianity is the least "spiritual" of all religions, its heart quickening not so much to ideas or mystical experience as to people streaming out of Egypt and crucifixions. History is the arena of revelation and the locus of discipleship. The faith is not so much an escape from the vicissitudes of life as an engagement in them. The prophets thus speak not only of spiritual idolatry but of social injustice, of military alliances, and commercial justice at the gate.

With this prophetic perspective, the religious community will hear nothing of "sticking to religion." In fact it is "sticking to religion," in the narrow sense of rituals and doctrines, that caused the prophet to declare that such acts had become a stench in the nostrils of a God who demanded justice and righteousness in a whole nation's life. The Christian will continue to seek to manifest righteousness in every arena of life and to look to the mundane, worldly and earthly for manifestations of judgment and grace. To preach salvation is, to be sure, to speak of the individual's capacity to be born from above and experience the fulness of Christ's forgiveness and the indwelling of the spirit, but it is also to recognize the plea in Romans and the promise in Ephesians that all creation comes to acknowledge God and find its unity in Him. In fact, the salvation of the individual is but a part of God's full intent, manifested in creation, to exercise his Lordship over all creation.

The delaration of Christ's "Lordship" is perhaps the most comprehensive and revolutionary statement of the gospel and one increasingly proclaimed in the evangelical community. The term is not, as so often seems the case in religious prayer and conversation, 
a term of endearment or a synonym for "sweet" or "kind." In the New Testament, it is the Greek "kyrios" which is cognate to "caesar," "kaiser" and "czar"-none of whom were noted for sweetness. They were noted for power and authority. It is the declaration of the final and ultimate authority of Christ. Ephesian Christians in the Roman empire did not court hostility because they thought Jesus was "sweet" or because they thought they would go to heaven when they died. They did not anger Romans or worshippers of Diana because they thought the teachings of Jesus were good advice. What Rome could not tolerate was the assertion by Ephesian Christians that Jesus was "kyrios," because that was a direct assault on the Roman assertion of final authority.

The practical consequence of this assertion that Christ is Lord of all is that the evangelical Christian community will resist the attempt to constrain its activities to what the secularist defines as "religion." Politics, art, science and philosophy are all part of the arena of activity by the believing community. The criticism of religious groups on the right based on their involvement in politics is particularly ill conceived. One may indeed debate their choice of issues or even the side they take on some, but no one emerging from the biblical tradition dare challenge their assertion that as believers they feel compelled to speak to the moral character and the political life of the nation.

Thus those informed by the prophetic tradition will not be satisfied with being left alone. They will seek a structure which allows dialogue, engagement, judgment and restoration. Free exercise will not be construed as merely creating a zone of non-governmental interference or the creation of an exemption from conscience-opposed activity, but the opportunity to be full partners in the pluralism of our day. The believer will not, of course always be politically successful, and he must be sensitive to the rights of others, eager to perserve wide zones of freedom for all persons.

Related to the commitment to history, of course, is a commitment to the role of community and culture in shaping life. In the Old Testament in particular there is the clear recognition that not just individuals but nations have a personality and character. The concept of covenant and community, even the role of law in that community, give evidence of the biblical commitment to culture. Culture is expressive or resistive to covenant living, to righteousness and justice. And quite clearly community and culture are broader than religion, narrowly conceived. Culture and community includes 
civil law and government. These too are gifts of God. It is not only religion which gives a gift to culture, but government as well. The believer will thus be concerned to assist in a crucial dialogue in our society about the relationship of community and its values and sustaining traditions of the rights of individuals. This will surely raise complex issues such as those in the classic Hart-Devlin debates, but it is an essential conversation. Christians should be joining those who raise serious sociological and psychological questions about the American enamoration with individualism often at the cost of the community. How to sustain community values, how to sustain a culture's values and traditions, how to avoid losing one's roots without overwhelming important liberties of individuals and minority groups are difficult issues, and profoundly pressing ones.

The biological concept of territoriality, which refers to the social habits of some animals in staking out a piece of turf, a territory which is theirs, is instructive. Conflicts emerge when there is an invasion of another's territory. There is a sense in which a version of the concept of territoriality is used by some to suggest that religionists ought to stay in their place. Such persons offer the religious person a certain territory-usually the offer includes prayers, worship services, bibles, gospel singing and, of course, everything after we die. Such a restriction must be vigorously rejected as contrary not only to our understanding of the scope of our faith commitment, but contrary to that which gives health and vitality to a civilization. Surely in the crises of our culture, it is only a loss to exclude from the nurturing and sustaining elements, the insights and gift of faith. Rather than seeking to exclude from all public presence the strengths of religious communities and faith, our culture ought to be encouraging the participation in public life of all those who come with some values and commitments worth giving one's life to.

This perspective on the significance of the historical process in God's story gives to the believing community a special task to develop an adequate philosophy of history, of culture and of the place of government in God's order. Today the issues raised in H. Richard Niebuhr's classic volume, CHRIST AND CULTURE, are urgent. No legal strategy for First Amendment liberties, no arguments for Free Exercise, no attempt to preserve the spiritual values of our heritage dare ignore the necessity of a prior task of philosophy. Only through such a task can we also avoid the dangers inherent in a misapplication of the notion of Christ's reign over all creation and history, specifically, the dangers are those of baptizing what is with 
God's will and freezing His work-the ideologization of history; and the danger of the crusades-the immediate and human establishment of His authority.

\section{What OF THE RESPONSE}

Even granting the accuracy of many of the perceptions of these evangelicals, the question may still be asked whether their response is appropriate, or even whether their interpretive framework for these events is adequate. Of course, to many, the evangelical's sense of disequilibrium is merely a problem created by themselves and their religious fantasies and antiquarian views of society and human life. Thus the evangelical foray is belittled as a remnant of some McCarthyite urge, the product of a dangerous moral censor about to strike at the root of our liberties and threaten the fabric of democracy. The movement cannot, however, be dismissed so cavalierly. 